\title{
Spor Yöneticilerinin İletişim Beceri Düzeylerinin İşgörenlerin Motivasyonu Üzerine Etkisi
}

\author{
Cemil BOZ ${ }^{1}$, Turgay BİÇER ${ }^{2}$, Kaan SERTER ${ }^{3}$, Koray Emre KARA ${ }^{4}$ ve \\ Murat ŞENTUNA ${ }^{5}$
}

$\ddot{\mathrm{O} z}$

Araştırmada, İstanbul Gençlik ve Spor İl Müdürlügü’nde görev yapan spor yöneticilerinin iletişim beceri düzeylerinin, işgörenlerinin iş motivasyonları üzerindeki etkilerinin bulunmasını amaçlanmıştır. Araştırmada betimsel araştırma yöntemi ve veri toplama tekniği olarak anket tekniği kullanılmışır. Araştırmanın evrenini, İstanbul Gençlik ve Spor İl Müdürlüğü’nde görev yapan 88 yönetici ile 1994 işgören olușturmaktadır. Çalıșmaya gönüllülük esasına göre 77 yönetici ile 412 işgören katılmıștır. Veri toplama araçları olarak, yöneticiler için 1996 yllında Korkut tarafından geliştirilen ve 25 maddeden oluşan İletişim Becerilerini Değerlendirme Ölçeği (İBDÖ), işgörenler için ise 1985 yllında Mottaz tarafından geliştirilip Dündar ve arkadaşları (2007) tarafindan Türkçe uyarlaması yapılmış olan ve 24 maddeden oluşan İş Motivasyonu Ölçeği (IMOÖ) kullanılmıştır. Araştırmanın verilerini test etmek için, aritmetik ortalama, standart sapma, standart hata, Shapiro-Wilk testi, basıklık ve çarpıklık değerleri testi, bağımsız grup t-testi, tek yönlü varyans analizi (ANOVA), TUKEY testi ve korelasyon analizi test yöntemleri kullanılmıştır. Araştırma sonucunda, yöneticilerin iletișim beceri düzeylerinin yüksek $(A O=4,32)$ düzeyde, ișgörenlerin motivasyon düzeylerinin orta $(\mathrm{AO}=3,27)$ düzeyde olduğu tespit edilmiştir. Ayrıca araştırmaya katılan yöneticilerin iletişim beceri düzeyleri ve işgörenlerin iş motivasyon düzeyleri arasında olumlu yönde çok zayıf bir ilişki saptanmıştır ( $\mathrm{r}=.079 ; \mathrm{p}>.05)$.

Anabtar Kelimeler: Yönetim, İletişim, Motivasyon, Yönetici, İşgören

\section{The Effect of Sports Managers Communication Skill Levels on Motivation of Employees}

\begin{abstract}
The aim of the study was to find the effects of communication skill levels of sports managers working in Istanbul Youth and Sports Provincial Directorate on the business motivations of their employees. In the research, descriptive research method and survey technique were used as data collection technique. The universe of research consists of 88 managers working in the Istanbul Provincial Directorate of Youth and sports and 1994 employees. 77 managers and 412 employees participated in the study on a voluntary basis. As data collection tools for administrators developed by Korkut in 1996 and consists of 25 items, and the scale for assessment of communication skills (IBDO), and Dundar and colleagues in 1985 for employees developed by mottaz (2007) a Turkish adaptation made by, and consists of 24 items, and work motivation scale (IMO) was used. To test of the research data, arithmetic mean, standard deviation, standard errors Shapiro-Wilk test, skewness and kurtosis values of the test, Independent Group t-test, one way analysis of variance (Anova), Turkey's test and correlation analysis test methods were used. As a result of the research, it was found that the communication skill levels of managers were high $(\mathrm{AO}=4.32)$ and the motivation levels of employees were moderate $(\mathrm{AO}=3.27)$. In addition, a very weak association was found between the communication skill levels of managers and the business motivation levels of employees participating in the study $(r=.079$; p.05).
\end{abstract}

Key Words: Management, Communication, Motivation, Manager, Worker

\section{Atıf İçin / Please Cite As:}

Boz, C., Biçer, T., Serter, K., Kara, K. E ve Şentuna, M. (2021). Spor yöneticilerinin iletişim beceri düzeylerinin ișgörenlerin motivasyonu üzerine etkisi. Manas Sosyal Araștrrmalar Dergisi, 10(1), $492-502$.

Geliş Tarihi / Received Date: 25.04.2020

Kabul Tarihi / Accepted Date: 14.10.2020

\footnotetext{
${ }^{1}$ Doktora Öğrencisi- Marmara Üniversitesi Spor Bilimleri Fakültesi, cemilboz@gmail.com

iD ORCID: 0000-0002-7340-7851

2 Prof. Dr.- Marmara Üniversitesi Spor Bilimleri Fakültesi, turgay@marmara.edu.tr

(iD) ORCID: 0000-0002-0343-5101

${ }^{3}$ Doktora Özel Öğrencisi- Marmara Üniversitesi Spor Bilimleri Fakültesi, kaanserter@hemsball.com

iD ORCID: 0000-0002-5089-8467

${ }^{4}$ Dr. Öğr. Üyesi- İstanbul Gelişim Üniversitesi / İstanbul Gençlik ve Spor İl Müdürlüğü, korayemrekara@hotmail.com

iD ORCID: 0000-0002-2515-1679

${ }_{5}^{5}$ Doç. Dr.- Aydın Adnan Menderes Üniversitesi Spor Bilimleri Fakültesi, tarumnil@gmail.com

(iD) ORCID: 0000-0001-7728-7933
} 


\section{Giriş}

İletișimin bireylerarası etkileşiminin en temel öğesi olduğu söylenebilir. Toplumda güven verici ve doyurucu ilişkileri sürdürebilmek, iletişim becerilerinin niteliğine ve kalitesine bağlıdır. Öztürk ve Soytürk (2019, s. 588), iletişimi hayatın her noktasında evlerde, işyerlerinde ve sokakta zorunlu bir ihtiyaç olan önemli bir kavram olarak görür; hatta toplumsal hayatta ve örgütlerde başarılı ilişkilerin kurulmasını etkili iletişime bağlarken, özellikle yüz yüze ilişkilerin kurulduğu meslek gruplarında, bireylerin iletişim becerilerinin kalitesinin çok önemli olduğunu belirtir.

İngilizce "communication" sözcügünün Türkçede ki karşılığ1 olan iletişimin, kökeni "communis" sözcügüdür. Latince bir sözcük olan communis, birçok nesneye veya birçok kişiye ait ortaklaşa gerçekleştirilen anlamı taşımaktadır(Zillıŏglu, 2007, s. 22).Demirtaş (2010, s. 413) iletişimi, bir sonuca ulaşabilmek için kişinin tutum ve davranışlarını etkileyebilmek için duygularını, inançlarını, düşüncelerini ve tutumlarını sözlü-sözsüz ya da yazılı olarak iletebilme süreci olarak tanımlamaya çalışırken, Oskay (2019, s. 23) iletişimi, bireyin varlığını sürdürme biçimi ve bu biçimdeki gelişmelere göre değişimlere uğrayan bireye has bir sonuç olarak tanımlar. Bir diğer tanım da ise Biçer (2006, s. 50) iletişimi tanımlarken yaptı̆̆ vurgularda "bireyin ne dediğinden çok, karşısındakinin ne anladığıdır" diyerek farklı bir pencereden bakmış ve "bireyin yaşam kalitesini, kendisi ve başkaları ile kurduğu iletişimin kalitesi belirler" diyerek iletişimin önemini konuşmaktan daha çok nasıl anlaşıldığının altını çizmiştir.

İletişimin kurumsal boyutu olan örgütsel iletişimi Borca ve Baesu (2014, s. 498), örgütlenmiş bir kurumsal yapının bölümleri arasında, örgütün motive edilmesi ile örgütsel çevresi ve kendi işgörenleri ile diğer paydaşlar arasında başarı ihtiyacının bilgisi, deneyimi ve veri akışı arasında bağlantı sağlayan sosyal, ekonomik ve teknik bir süreç olarak tanımlamaktadır. Tutar (2003, s. 83) ise örgütsel iletişimi; örgütün amaç ve hedeflerini gerçekleştirmek için çalışanların ileti alışverişi yapmaları, etkileşim ve iş birliği hâlinde olmaları şeklinde ifade eder. Örgütsel iletişimin örgütteki işgörenler arasında alg1, veri ve bilgi düşüncelerin iletilmesi işlevi bulunmaktadır (Şimşek, 2002, s. 198). Örgütsel amaçlar için işgörenlerin etkin ve verimli çalısmalarının sağlanması gerekmekte olup işgörenlerin motivasyonunu sağlamak, güvenli bir ortam oluşturmak, kurum amaç ve hedeflerini geliştirmek gibi görevler yöneticinin görevleri arasında yer aldığını dile getiren Van Riel (1995), ayrıca bu görevlerin yerine getirilebilmesi için yöneticinin etkili iletişim becerilerine ayrı bir yetkinlik olarak sahip olması da gerektiğinin de üzerini çizmektedir (Van Riel, 1995 Akt: Öksüz, 2018, s. 5). Yöneticilerin örgütsel alanda kullandığ1 temel bir araçlardan biri de iletişimdir (Koçel, 2001, s. 417).

Örgütlerin amaçlarına ulaşabilmeleri, örgütsel iletişim sürecine bağlıdır. Bu nedenledir ki örgütsel iletişim, yönetimin temel fonksiyonlarından biridir. Örgütlerde, gerekli koordinasyonun sağlanması, planlamanın yapılması ve faaliyetlerin yürütülebilmesi için iyi bir iletişim sistemine ihtiyaç vardır (Atak, 2005, s. 60-61). Örgütteki işgörenler işlerin nasıl yapılacağını, ekip arkadaşlarının veya amirlerinin kendileri hakkında ki düşüncelerini ve kendilerinden neler beklendiğini iletişim sayesinde öğrenme olanağı bulurlar. Örgütsel iletişimin etkinliği, örgütsel bağlllık, motivasyon ve iş tatmini gibi faktörlerle işgörenlerin davranışlarında olumlu bir etki yaratmaktadır. Ayrıca işgörenlerin tutumlarının olumlu yönde olmasında etkili iletişimin rolü büyüktür (Kıraç, 2012, s. 37).

İsteklendirme veya güdüleme olarak Türkçede kullanılan motivasyon sözcüğü "motive” fiilinden türetilerek kullanılmaktadır (Eren, 1993 Akt: Timuroğlu ve Balkaya, 2017, s. 95). Motivasyon, belirlenen amaçlara ulaşmak için bireyin davranışlarında ki hareketliliği sürekli olarak devam ettiren, bu davranışlara yönelten süreçlerin tümüdür (Greenberg ve Baron, 2000 Akt: Ateş ve Buluç, 2018, s. 2). Diğer tanımda ise motivasyon, bireyi bir hedefe yönelten, o amaç için harekete geçirip bu hareketin devamlllı̆̆ını sağlayan, bireyin iç ve dış dünyasından kaynaklanan enerjiler bütünü olarak tanımlanır (Timuroğlu ve Balkaya, 2017, s. 91).

Pinder (2014) iş motivasyonunu, kendisiyle ilgili davranışı ortaya çıkaran ve yönünü, sıklığını, şeklini ve süresini belirleyebilmek amacıyla bireyin iç ve dış dünyasında meydana gelen enerjik güçler bütünü olarak tanımlar (Pinder, 2014 Akt: Timuroğlu ve Balkaya, 2017, s. 95). İş motivasyonunda işgörenlerin davranışlarını bilmek ve davranışlarının arkasındaki nedenleri iyi analiz edebilmek önemli bir konudur (Karaçar, 2019, s. 63). Modern yönetim anlayışında odakta yer alan bireyin isteği önemlidir. İşgörenlerin ve örgütlerin performansı motivasyon ile artır1labilir (Dündar, Özutku ve Taşpınar, 2007, s. 116). Alan yazın incelendiğinde iş motivasyonun işgörenlerin seviyelerini açıklayan çok farklı gruplandırmaların olduğu 
görülür. İkili Faktör Kuramı’nda Frederick Herzberg iş motivasyonunu içsel ve dışsal olarak iki boyutta ele almıştır. Mottaz (1985, s. 365-385) içsel motivasyon araçlarını görevin işgören bakımından önemi, işgörenin işe katılımı ve sorumluluğu, görevin zorlayıcı ve ilgi çekici olması olarak belirtir. Dışsal motivasyonu ise Abbasoğlu (2015, s. 33) çevrenin işgörenin davranışlarını kontrol etmesi ile başlayan süreç olarak tanımlar. İşgörenin birlikte çalıștı̆ı arkadaşlar veya yöneticilerinden gelen ödül veya cezalar dışsal motivasyon araçlarına örneklerdir. Kurumlarda görev yapan yöneticilerin iletişim becerilerinin üst seviyede olması, işgörenleri daha iyi tanımalarına ve onların istek ve beklentilerini karşılamalarını olanak sağlayarak, onların motivasyonlarının artmasına sebep olacağı gibi kurumsal yapının güçlenmesini ve iş ortamında mutluluk ve huzurun hâkim olmasına neden olabilir. Ayrıca iş ortamında mutluluk ve huzuru yakalayan bir işgörenin sosyal hayatta ki mutluluğu da yadsınamayacak gerçeklerden biridir. Araştırmayı bu bağlamda ele alıp kurumda görev yapan yöneticilerin iletişim beceri düzeylerinin işgörenlerin motivasyonuna etkisi incelenmiştir.

\section{Yöntem}

İstanbul Gençlik ve Spor İl Müdürlügü’nde görev yapan yöneticilerin iletişim beceri seviyeleri ile işgörenlerin iş motivasyonu seviyeleri arasındaki ilişkiyi belirlemeye çalışlan araştırmada, nicel araştırma tekniklerinden mevcut durumu ortaya çıkartmayı amaçlayan betimsel araştırma yöntemi kullanılmıştır. Geçmişte var olmuş veya hâlihazırda mevcut durumu olduğu hali ile açıklamaya çalışan bu yöntem çok kullanılan bir araştırma yöntemidir (Karasar, 2006, s. 77).

\section{Evren - Örneklem}

Araştırmanın evrenini, İstanbul Gençlik ve Spor İl Müdürlügü̉nde görev yapan 88 yönetici ile 1994 işgören oluşturmaktadır. Araştırmada kattlımcıların gönüllülük esasına göre 77 yönetici ile 412 işgören katılmıştır. Örneklem grubunun doğru örneklem tekniğine göre evreni temsil ettiği kabul edilmiştir.

\section{Veri Toplama Araçları}

Verileri toplamak için anket tekniği kullanılmıştır. Kullanılan anketler hem yöneticiler için hem de işgörenler için ikişer bölümden oluşmaktadır. Yöneticiler için birinci bölümde araştırmacılar tarafından hazırlanan cinsiyet, medeni durum, eğitim durumu, yaş, yönetici olarak çalşstı̆ı süre ve gelir durumu demografik bilgiler olarak hazırlanan kişisel bilgi formu ile toplanmıştır. İkinci bölümde, 1996 yllında Korkut (s. 18-23) tarafindan yapılan bir çalışmada ile geliştirilerek geçerlilik ve güvenirliği yapılan, 25 madde içeren beşli likert ölçeği olan İletişim Becerilerini Değerlendirme Ölçeği (IBBDÖ) kullanılmışır. Tersine maddelerinin bulunmadığı ölçekte alınan yüksek puan, katılımcıların iletişim beceri düzeylerinin yüksek olduğu anlamına gelmektedir. İşgörenler için ise çalışmayı yapan araştırmacılar tarafindan hazırlanan yaş, cinsiyet, medeni durum, eğitim durumu, kurumdaki görevi, kurumdaki görev süresi, gelir durumu demografik bilgiler olarak kişisel bilgi formunda yer almaktadır. İkinci bölümde de 1985 y1lında Mottaz (s. 365-385) tarafindan geliştirilip Dündar ve arkadaşları (2007, s. 105-119) tarafindan Türkçe uyarlaması yapılmış 24 maddeli ve beşli likert türünde bir ölçek olanİş Motivasyonu Ölçeği (İMÖ) kullanılmıştır. İMÖ beşli likert tipinde hazırlanmış bir ölçektir. Ölçek değerlendirilirken 1.00 ve 1.80 aralı̆̆1 çok düşük, 1.81 ve 2.60 aralı̆̆1 düşük, 2.61 ve 3.40 aralığ1 orta, 3.41 ve 4.20 aralığ1 yüksek, 4.21 ve 5.00 aralığ1 çok yüksek olarak değerlendirilir. Ölçek temel olarak içsel ve dişsal motivasyon boyutundan oluşmaktadır. İMÖ'nün 9 maddesi içsel motivasyon boyutunu, 15 maddesi ise dişsal motivasyon boyutunu açıklamaktadır.

\section{Verilerin Analizi}

Araştırmada ortalama, standart hata ve sapma, Shapiro-Wilk testi, basıklık-çarpıklık değerleri, T-testi, ANOVA testi, TUKEY testi ve korelasyon analizi test yöntemleri kullanılmıstır. 


\section{Bulgular}

Bu bölümde ölçekler yoluyla elde edilen verilerin yapılan analizleri sonucunda ulaşılan bulgulara yer verilmektedir.

Tablo 1. Yöneticilerin Demografik Bilgileri Frekans Tablosu

\begin{tabular}{|c|c|c|c|}
\hline Değişken & Düzey & $n$ & $\%$ \\
\hline \multirow{2}{*}{ Cinsiyet } & Kadin & 19 & 24,7 \\
\hline & Erkek & 58 & 75,3 \\
\hline \multirow{2}{*}{ Medeni Durum } & Evli & 64 & 83,1 \\
\hline & Bekâr & 13 & 16,9 \\
\hline \multirow{3}{*}{ Eğitim Durumu } & Lisans & 49 & 63,6 \\
\hline & Yüksek Lisans & 25 & 32,5 \\
\hline & Doktora & 3 & 3,9 \\
\hline \multirow{4}{*}{ Yaş } & 30 yaş altı & 1 & 1,3 \\
\hline & $31-40$ yaș aras1 & 23 & 29,9 \\
\hline & $41-50$ yaș arası & 28 & 36,4 \\
\hline & 51 yaş ve üstü & 25 & 32,5 \\
\hline \multirow{3}{*}{ Yöneticilikteki Görev Süresi } & $0-5$ yil aras1 & 22 & 28,6 \\
\hline & $6-10$ yll aras1 & 17 & 22,1 \\
\hline & 11 yll ve üzeri & 38 & 49,4 \\
\hline \multirow{3}{*}{ Gelir Durumu } & 4000 TL ve alt1 & 6 & 7,8 \\
\hline & 4001-5000 TL aras1 & 16 & 20,8 \\
\hline & 5001 TL ve üstü & 55 & 71,4 \\
\hline Toplam & & 77 & 100,0 \\
\hline
\end{tabular}

Tablo 1'de; kat1lımc1 yöneticilerin 58'i (\%75,3) erkek, 19’u (\%24,7) kadındır. 64'ü $(\% 83,1)$ evli iken 13’ü (\%16,9) bekârdır. Eğitim durumları incelendiğinde, 49 yönetici $(\% 63,6)$ lisans, 25’i $(\% 32,5)$ yüksek lisans ve 3 'ü de $(\% 3,9)$ doktora mezunudur. 30 yaş altı $1(\% 1,3)$ yönetici bulunurken, 31 ile 40 yaş arası 23 $(\% 29,9), 41$ ile 50 yaş arası $28(\% 36,4)$ ve 51 yaş ve üstü yönetici sayısı ise 25 'dir $(\% 32,5)$. Yöneticilerin yöneticilikteki görev sürelerine bakıldığı zaman $0-5$ yıl arası yöneticilik yapanların sayısı $22(\% 28,6)$ iken, 610 yıl arası yöneticilik yapanların sayısı 17 (\%22,1), 11 yıl ve üzeri yöneticilikte bulunan yönetici sayısı da 38 'dir (\%49,4). Gelir durumları incelendiğinde, 6 yöneticinin $(\% 7,8) 4000$ TL ve alt1, $16(\% 20,8)$ yöneticinin 4001-5000 TL aras1 ve 55 yöneticinin de $(\% 71,4) 5001$ TL ve üstü gelire sahip olduğu görülmektedir.

Tablo 2. İsgörenlerin Demografik Bilgileri Frekans Tablosu

\begin{tabular}{|c|c|c|c|}
\hline Değgişken & Düzey & $\bar{n}$ & $\%$ \\
\hline \multirow{2}{*}{ Cinsiyet } & Kadin & 174 & 42,2 \\
\hline & Erkek & 238 & 57,8 \\
\hline \multirow{2}{*}{ Medeni Durum } & Evli & 288 & 69,9 \\
\hline & Bekar & 124 & 30,1 \\
\hline \multirow{4}{*}{ Eğitim Durumu } & İlkokul ve Ortaokul & 43 & 10,4 \\
\hline & Lise & 60 & 14,6 \\
\hline & Lisans & 258 & 62,6 \\
\hline & Lisansüstü & 51 & 12,4 \\
\hline \multirow{4}{*}{ Yaş } & 18-30 yaş aras1 & 101 & 24,5 \\
\hline & $31-40$ yaş arası & 189 & 45,9 \\
\hline & $41-50$ yaş arası & 80 & 19,4 \\
\hline & 51 yaş ve üstü & 42 & 10,2 \\
\hline \multirow{3}{*}{ Kurumdaki Görev Süresi } & 05 yil aras1 & 202 & 49,0 \\
\hline & $6-10$ yll aras1 & 123 & 29,9 \\
\hline & 11 y1l ve üzeri & 87 & 21,1 \\
\hline \multirow{3}{*}{ Gelir Durumu } & 2000-3000 TL aras1 & 94 & 22,8 \\
\hline & $3001-4000$ TL aras 1 & 255 & 61,9 \\
\hline & 4001 TL ve üstü & 63 & 15,3 \\
\hline \multirow{2}{*}{ Kurumdaki Görevi } & Memur & 294 & 71,4 \\
\hline & İşçi & 118 & 28,6 \\
\hline Toplam & & 412 & 100,0 \\
\hline
\end{tabular}


Tablo 2'de görülen verilerde; işgörenlerin 238’i (\%57,8) erkek, 174'ü (\%42,2) kadındır. 288’i (\%69,9) evli iken 124'ü $(\% 30,1)$ bekârdır. İşgörenlerin eğitim durumları incelendiğinde, 43’ü $(\% 10,4)$ ilkokul veya ortaokul, 60’1 (\%14,6) lise, 258'i (\%62,6) lisans ve 51'i ise $(\% 12,4)$ lisansüstü mezunudur. 18 ile 30 yaş aras1 $101(\% 24,5)$ işgören bulunurken, 31 ile 40 yaş arası $189(\% 45,9), 41$ ile 50 yaş arası $80(\% 19,4)$ ve 51 yaş ve üstü işgören sayısı ise 42'dir (\%10,2). İşgörenlerin kurumdaki görev sürelerine bakıldığ1 zaman 0-5 y1l arası kurumda görev yapanların sayıs1 $202(\% 49,0)$ iken, 6-10 y1l aras1 kurumda görev yapanların sayıs1 123 $(\% 29,9), 11$ y1l ve üzeri kurumda görev yapanların sayısı da 87’dir (\%21,1). İşörenlerin gelir durumları incelendiğinde, 94'ünün (\%22,8) 2000-3000 TL aras1, 255’inin (\%61,9) 3001-4000 TL aras1 ve 63'ünün de $(\% 15,3) 4001$ TL ve üstü bir gelir düzeyine sahip olduğu görülmektedir.

Tablo 3. Yöneticilerin IBDÖ ile İgörenlerin IMÖ'ne ait Ortalama, Standart Sapma ve Hata, Normallik, Carpıklık ve Basıklik Değerleri Tablosu

\begin{tabular}{|c|c|c|c|c|c|c|c|c|c|c|}
\hline \multirow{2}{*}{$\begin{array}{l}\text { Ölçek ve } \\
\text { Boyutlar1 }\end{array}$} & \multirow{2}{*}{$\mathbf{n}$} & \multirow{2}{*}{ AO } & \multirow{2}{*}{$\mathbf{S}$} & \multirow{2}{*}{$\mathrm{Sh}_{\mathrm{x}}$} & \multicolumn{2}{|c|}{ Shapiro-Wilk } & \multicolumn{2}{|c|}{ Basıklık } & \multicolumn{2}{|c|}{ Çarpıklık } \\
\hline & & & & & $\mathrm{Z}$ & $\mathrm{p}$ & Değer & $\mathrm{Sh}_{\mathrm{x}}$ & Değer & $\mathrm{Sh}_{\mathrm{x}}$ \\
\hline İBDÖ & 77 & 4,32 & .41 & .04 & .957 & .011 & $-1,042$ & .541 & .066 & .274 \\
\hline İMÖ & 412 & 3,27 & .59 & .02 & .990 & .006 & .088 & .240 & -.313 & .120 \\
\hline İçsel Motivasyon & 412 & 3,91 & .73 & .03 & .942 & .000 & .917 & .240 & -.919 & .120 \\
\hline Dişsal Motivasyon & 412 & 2,89 & .61 & .03 & .996 & .389 & -.157 & .240 & -.010 & .120 \\
\hline
\end{tabular}

Tablo 3'de, yöneticilerin İBDÖ aritmetik ortalaması ( $\mathrm{AO}=4,32)$, işgörenlerin İÖ aritmetik ortalaması $(\mathrm{AO}=3,27)$ olarak bulunmuştur. Elde edilen bulgulardan hareketle yöneticilerin iletişim beceri düzeylerini belirlemek için hazırlanan ölçek maddelerine yüksek düzeyde katıldıkları ve iletişim beceri düzeylerinin yüksek düzey olarak nitelendirdikleri, işgörenlerin iş motivasyon düzeylerini belirlemek için hazırlanan ölçek maddelerine orta düzeyde katıldıkları ve iş motivasyon düzeylerinin orta düzey olarak nitelendirdikleri söylenebilir. Ayrıca işgörenlerin içsel motivasyon düzeyleri $(A O=3,91)$, dişsal motivasyon düzeylerine $(\mathrm{AO}=2,89)$ göre daha yüksektir.

İBDÖ ile İMÖ puanları dağılımının normalliğini test etmek için yapılan Shapiro-Wilk testinin ardından İBDÖ puanlarının ( $z=.957 ; p<.05)$, IMÖ puanlarının $(z=.990 ; p<.05)$ dağılımlarının normal dağılım göstermediği, normallik testinin sonuçlarına göre basıklık-çarpıklık değerinin \pm 1.5 aralığında olduğu anlaşılmaktadır. Tabachnick ve Fidell'e göre (2013, s. 67-73) bu aralıktaki değerler kabul edilebilir bir durum oluşturmaktadır. Bu çalışmada da dağılımın normal olduğu kabul edilebilir.

Yöneticilerin İBDÖ aritmetik ortalamaları ve işgörenlerin IMÖ aritmetik ortalamaları ile cinsiyete göre farkın anlamlı olup olmadığının tespit edilmesi için uygulanan t-testinin sonuçlarına Tablo 4'te yer verilmiştir.

Tablo 4. IBDÖ ile IMÖ’nin Cinsiyete Göre Farkın Anlamliluğm Gösteren t-Testi Sonuclar Tablosu

\begin{tabular}{|c|c|c|c|c|c|c|c|c|}
\hline \multirow{2}{*}{ Ölçek } & \multirow{2}{*}{ Değişken } & \multirow{2}{*}{$\mathbf{n}$} & \multirow{2}{*}{ AO } & \multirow{2}{*}{$\mathbf{S}$} & \multirow{2}{*}{$\mathrm{Sh}_{\mathrm{x}}$} & \multicolumn{3}{|c|}{ t-Testi } \\
\hline & & & & & & $T$ & $\mathrm{df}$ & $\mathrm{p}$ \\
\hline \multirow{2}{*}{ İBDÖ } & Kadın & 19 & 4,49 & .37 & .08 & \multirow{2}{*}{2,04} & \multirow{2}{*}{75} & \multirow{2}{*}{$.044 *$} \\
\hline & Erkek & 58 & 4,24 & .41 & .05 & & & \\
\hline \multirow{2}{*}{ İMÖ } & Kadin & 174 & 3,18 & .56 & .04 & \multirow{2}{*}{$-2,75$} & \multirow{2}{*}{410} & \multirow{2}{*}{$.006^{*}$} \\
\hline & Erkek & 238 & 3,34 & .60 & .03 & & & \\
\hline
\end{tabular}

Tablo 4'de ki sonuçlara göre, yöneticilerin İBDÖ aritmetik ortalamalarında cinsiyet değişkeninde anlamlı olduğu düşünülen bir fark görülmektedir $\left[\mathrm{t}_{(75)}=2,04, \mathrm{p}<.05\right]$. Ortaya çıkan bu farkın kadın yöneticilerin erkek yöneticilere göre iletişim beceri düzeylerinin daha yüksek olduğunu göstermektedir $(\mathrm{AO}=4,49)$. Ayrıca işgörenlerin İÖ̈ aritmetik ortalamalarının cinsiyete göre anlamlı olarak farklılık gösterdiği belirlenmiştir $\left[\mathrm{t}_{(410)}=-2,75, \mathrm{p}<.05\right]$. Bu fark ise erkek işgörenlerin iş motivasyonlarının kadın işgörenlere göre daha yüksek olduğunu ortaya koymuştur $(\mathrm{AO}=3,34)$.

Yöneticilerin İBDÖ cevaplarına göre yapılan t-testi sonuçlarında medeni durumları arasındaki aritmetik ortalamaları arasında $\left[\mathrm{t}_{(75)}=.540, \mathrm{p}>.05\right]$, işgörenlerin IMÖ cevaplarına göre medeni durumları $\left[\mathrm{t}_{(410)}=-.557, \mathrm{p}>.05\right]$ ve kurumdaki görevlerine $\left[\mathrm{t}_{(410)}=-.675, \mathrm{p}>.05\right]$ göre de anlamlı olduğu düşünülen bir farklılık bulunamamıştır.

İşgörenlerin eğitim durumlanı İBDÖ ve İMÖ cevaplarına göre yapılan ANOVA testi sonuçları Tablo 5'de verilmiştir. 
Tablo 5. IBDDÖ ile IMÖ’nin Eğitim Durumu Değişkenine Göre Farkın Anlamlihğgm Gösteren ANOVA Testi Sonuclar Tablosu

\begin{tabular}{|c|c|c|c|c|c|c|c|c|}
\hline Ölçek & Değişken & $\mathbf{n}$ & AO & $\mathrm{S}$ & sd & $\mathbf{F}$ & $\mathbf{P}$ & $\begin{array}{c}\text { Anlamli } \\
\text { Fark } \\
\text { (TUKEY) } \\
\end{array}$ \\
\hline \multirow{4}{*}{ İMÖ } & İlk. ve Ortaokul & 43 & 3,22 & .77 & 3 & \multirow{4}{*}{2,84} & \multirow{4}{*}{$.038 *$} & \\
\hline & Lise & 60 & 3,47 & .53 & 408 & & & $.2241 *$ \\
\hline & Lisans & 258 & 3,25 & .56 & 411 & & & $-.2241 *$ \\
\hline & Lisansüstü & 51 & 3,20 & .54 & & & & \\
\hline \multirow{3}{*}{ İBDÖ } & Lisans & 49 & 4,37 & .42 & 2 & \multirow{3}{*}{1,93} & \multirow{3}{*}{.151} & \\
\hline & Yüksek Lisans & 25 & 4,28 & .38 & 74 & & & \\
\hline & Doktora & 3 & 3,92 & .40 & 76 & & & \\
\hline
\end{tabular}

Tablo 5'de görüldüğü üzere, işgörenlerin IMÖ̈ aritmetik ortalamalarında eğitim durumuna göre anlamlı olduğu düşünülen bir fark görülmektedir $\left[\mathrm{F}_{(3-411)}=2,84, \mathrm{p}<.05\right]$. Bu sebeple tamamlayıc1 Post Hoc analizine olan Levene's testi yapılmış ve varyansların homojen olduğu belirlenmiştir ( $\mathrm{LF}=2,52 ; .057$ ). Ardından TUKEY testi yapılmış ve sonucunda; lisans seviyesinden mezun olan işgörenler ile lise seviyesinden mezun olan işgörenler arasında, lisans seviyesinden mezun olan işgörenler lehine anlamlı bir farklllık belirlenmiştir. Bu fark lisans mezunu işgörenlerin lise mezunu işgörenlere göre motivasyon düzeylerinin daha yüksek düzeyde olduğunu göstermektedir. Test edilen alt boyutlar arasında görülen farklılık ise anlamlı bir düzeyde bulunmamıştır ( $\mathrm{p}>.05)$. Ayrıca işgörenlerin İMÖ aritmetik ortalamalarının yaş $\left[\mathrm{F}_{(3-411)}=2,42, \mathrm{p}>.05\right]$, kurumdaki görev süresi $\left[\mathrm{F}_{(2-411)}=2,29, \mathrm{p}^{>} .05\right]$ ve gelir durumu $\left[\mathrm{F}_{(2-411)}=.23\right.$, $\mathrm{p}>$.05]değişkenlerine göre yapılan ANOVA testi sonucunda, hiçbir değişkenin gruplarının ortalamaları arasinda beklenen anlamlı bir fark tespit edilememiştir.

Yöneticilerin İBDÖ aritmetik ortalamalarının eğitim durumu $\left[\mathrm{F}_{(2-76)}=1,93, \mathrm{p}>.05\right]$, yaş $\left[\mathrm{F}_{(3-76)}=.30\right.$, $\mathrm{p}>$.05], yöneticilikteki görev süresi $\left[\mathrm{F}_{(2-76)}=.46, \mathrm{p}>.05\right]$ ve gelir durumu $\left[\mathrm{F}_{(2-76)}=.05, \mathrm{p}>.05\right]$ değişkenlerine göre anlamlı bir fark belirlenememiştir.

Yöneticilerin iletişim becerilerini değerlendirme düzeyleri ile işgörenlerin iş motivasyon düzeyleri arasında ki ilişkiyi açıklamak için Pearson Korelasyon testinin sonuçlarına Tablo 6'da yer verilmiştir.

Tablo 6. Yöneticilerin Illetişim Becerileri Düzeyleri ile İsgörenlerin Iss Motivasyonu Düzeyleri Arasinda ki İlişkiyi Belirlemek Üzere Yapulan Korelasyon Analizi Sonuclar Tablosu

\begin{tabular}{|c|c|c|c|}
\hline & & İş Motivasyonu & İletişim Becerileri \\
\hline \multirow{3}{*}{ İMÖ } & $\mathrm{r}$ & 1 & .079 \\
\hline & $\mathrm{p}$ & & .494. \\
\hline & $\mathrm{N}$ & 412 & 77 \\
\hline \multirow{3}{*}{ İBDÖ } & $\mathrm{r}$ & .079 & 1 \\
\hline & $\mathrm{p}$ & .494 & \\
\hline & $\mathrm{N}$ & 77 & 77 \\
\hline
\end{tabular}

Tablo 6’ya göre, işgörenlerin iş motivasyon düzeyi ile yöneticilerin iletişim beceri düzeyi arasında olumlu yönde ancak çok zayıf bir ilişki görülmektedir [r=.079; p>.05]. Bu sonuç, yöneticilerin iletişim beceri düzeylerinin artmasının çok zayıf düzeyde ve olumlu yönde işgörenlerin iş motivasyon düzeylerinin arttığını göstermektedir.

\section{Tartışma, Sonuç ve Öneriler}

Araştırmaya katılan yöneticilerin iletişim beceri düzeylerinin oldukça yüksek olduğu görülmektedir. Bunun nedeni, yöneticilerin hepsinin üniversite lisans ve üzeri eğitime sahip olmaları olarak gösterilebilir. Lisans seviyesi ve üzeri eğitim alan bireylerin kendilerini geliştirmeleri, yetersiz becerilerinin farkına ve bilincine varmaları ve bu becerileri arttırmak için çaba içerisinde olmaları beklenmektedir. Bu sebeple de iletişim beceri düzeylerinin yüksek düzeyde çıktı̆̆1 söylenebilir. Çetinkaya (2011, s. 571) öğretmen adayları, Çelik (2013, s. 64) eğitim yöneticileri, Yanık (2015, s. 1369) ve Arslan (2019, s. 152) üniversite öğrencileri, Serttaş ve Tanyıldızı (2019, s. 975) kamu iç denetçileri üzerinde yaptıkları araştırmalar da iletişim beceri düzeylerinin yüksek olduğu sonucuna ulaşmışlardır. Tüm bu araştırma sonuçları bu araştırmanın bulgularını da destekler niteliktedir. 
Yöneticilerin İBDÖ aritmetik ortalamalarının cinsiyet değişkenine göre, grupların ortalamaları arasında ki fark anlamlı bulunmuştur. Bu durum kadın yöneticilerin iletişim beceri düzeylerinin erkek yöneticilerin iletişim becerilerine göre yüksek olduğunu ortaya koymaktadır. Literatür incelendiğinde de genel olarak kadınların iletişim beceri düzeylerinin daha yüksek olduğu görülmektedir. Kadınların doğuştan gelen konuşma yetkinliğinin yanı sıra, sosyal, iş ve eğitim ortamlarında kendilerini nispeten erkeklere göre çok daha iyi ifade edebilme zorunluluklarının olduğu düşüncesi ve kendilerini ispat etmek istemeleri gibi nedenlerden dolayı bu sonucun oluştuğu düşünülebilir. Korkut (1996, s. 21), Çetinkaya (2011, s. 572), Nacar ve Tümkaya (2011, s. 498), Arslan (2019, s. 153), Serttaş ve Tanyıldız1 (2019, s. 978) yaptıkları çalışmalarda iletişim beceri düzeyi ile cinsiyet değişkeni arasındaki anlamlı farkın kadınlar lehine olarak bulmuş olup, bu durum araştırma ile paralellik göstermektedir.

Yöneticilerin İBDÖ aritmetik ortalamalarının, eğitim durumu, medeni durum, yaş, yöneticilikteki geçirdikleri görev süreleri ve gelir durumları değişkenlerine göre grupların ortalamaları arasında ki fark anlamlı bulunmamıştır. Böylece değişkenlerin iletişim beceri düzeyi üzerinde önemli bir etken olmadığ1 söylenebilir. Özdayı (2011, s. 67), Kumcağız vd. (2011, s. 53), Çelik (2013, s. 66), Gülüm (2019, s. 57) ve Serttaş ve Tanyıldızı (2019, s. 978) yaptıklanı çalışmalarda medeni durum değişkeni ile iletişim beceri düzeyleri arasinda; Sert (2018, s. 59-61), Atalay (2018, s. 503), Gülüm (2019, s. 63), Çelik (2013, s. 66) ve Serttaş ve Tanyıldızı (2019, s. 981) yaptıkları çalışmalarda eğitim durumu değişkeni ile iletişim beceri düzeyleri arasında; Sert (2018, s. 58), Atalay (2018, s. 502), Akyol (2019, s. 73), Gülüm (2019, s. 56) yaptıkları çalışmalarda yaş değişkeni ile iletişim beceri düzeyleri arasında ve Gülüm $(2019$, s. 58$)$ ise yaptı̆̆ araştırmada gelir durumu düzeyi ile iletişim beceri seviyeleri arasında anlamlı olduğu düşünülen bir fark tespit edememişlerdir. Çok sayıda yapılmış olan bu çalışmaların sonuçları bu araştırmanın sonuçlarını da destekler niteliktedir.

Araştırmaya katılan işgörenlerin iş motivasyon düzeylerinin orta düzeyde olduğu görülmektedir. Bu sonuca göre İstanbul Gençlik ve Spor Müdürlüğü’nde görev alan işgörenlerin iş motivasyonlarının arttırılmasına yönelik çalışmaların yapılması gerekliliğinin doğduğu söylenebilir. İşgörenlerin iş motivasyon düzeylerinin yüksek olabilmesi için hem içsel hem de dişsal motivasyon düzeylerinin yüksek olması gerekmektedir. Bunu sağlamak öncelikle yöneticilerin görevidir. Araştırmaya katılan işgörenlerin içsel motivasyonları dişsal motivasyon düzeylerine göre çok daha yüksektir. Bu durum işgörenlerin kendi mesleklerinden çok; yönetim, ücret, terfi, ödül, iletişim, eğitim ihtiyacı ve fiziksel şartlar gibi dişsal araçlar ile ilgili sorunları olduğu izlenimi vermektedir. Ersar1 ve Naktiyok (2012, s. 92) ile Ertürk (2016, s. 6) yaptıkları araştırmalarında işgörenlerin iş motivasyon düzeylerinin orta düzey olduğu sonucuna varmışlar ve bu durum araştırmayla paralellik göstermektedir.

İşgörenlerin İMÖ ölçeğine verdikleri cevaplara bakarak cinsiyete göre grupların ortalamaları arasındaki farkın anlamlı olduğu görülmüştür. Bu durum, erkek işgörenlerin, kadınlara göre iş motivasyon düzeylerinin daha yüksek düzeyde olduğunu ortaya koymaktadır. Çelik (2013, s. 69) tarafindan yapılan bir çalışmanın sonuçlarına göre cinsiyet ile motivasyon düzeyi arasında erkekler lehine anlamlı seviyede farklılıklar olduğu bulunmuştur. Bulunan bu sonucun bu araştırmanın sonuçlarını da destekler nitelikte olduğu söylenebilir.

İşgörenlerin IMÖ aritmetik ortalamaları eğitim durumuna göre, grupların ortalamaları arasında anlamlı olduğu düşünülen bir fark bulunmuştur. Fark ise lisans mezunu işgörenlerin iş motivasyon düzeyleri, lise mezunu işgörenlere göre daha yüksek olduğu yönündedir. Bu duruma göre öğrenim düzeyinin artması, bireylerin hem farkındalıklarının artmasına hem de kendilerini motive edebilmelerini sağlamalarına sebep olması ile açıklanabilir. Yıldız (2017, s. 47-48), Orhaner ve Mutlu (2018, s. 89-90) yaptıkları araştırmalarda eğitim durumu değişkeni ile motivasyon düzeyi arasında anlamlı farklılıklar bulmuştur ve bu sonuçlar da bu araştırma sonuçlarına benzerlik göstermektedir.

İşgörenlerin İMÖ ortalamalarının yaş, kurumdaki görev süresi, medeni durum, gelir durumu ve kurumdaki görev değişkenlerine göre grupların ortalamaları arasındaki fark anlamlı gözükmemektedir. $\mathrm{Bu}$ sonuç yaş, kurumdaki görev süresi, medeni durum, gelir durumu ve kurumdaki görev değişkenlerinin iş motivasyon düzeyi üzerinde önemli bir etken değildir. Yapılan birçok araştırmanın sonuçları da bu araştırmada bulunan sonuçlara benzerdir. Yılmaz (2009, s. 43-44), Yirmibeşcik (2015, s. 48), Gedik ve arkadaşları (2018, s. 95), Altunkaya (2019, s. 114-115) ve Fidan (2019, s. 76) yaptıkları çalışmalarında yaş ile motivasyon düzeyi arasında, Yirmibeşcik (2015, s. 50) ve Altunkaya (2019, s. 116-117) kurumdaki görev süresi değişkeni ile motivasyon düzeyi arasında, Çelik (2013, s. 69), Gedik ve arkadaşlanı (2018, s. 96), 
Balıbey ve Öndaş (2018, s. 181), Fidan (2019, s. 75), Nal ve Sevim (2019, s. 403) ve Altunkaya (2019, s. 110) medeni durum ile motivasyon düzeyi arasında, Gedik ve arkadaşları $(2018$, s. 96) gelir durumu ile motivasyon düzeyi arasında anlamlı ve belirgin bir farklılık olmadığı sonucuna ulaşmışlardır.

Araştırmaya katılmış olan yöneticilerin iletişim beceri seviyeleri ile işgörenlerin iş motivasyon düzeyleri arasında olumlu yönde çok zayıf bir ilişki görülmektedir. Bu sonuç, yöneticilerin iletişim beceri düzeylerinin artmasının çok zayıf düzeyde işgörenlerin iş motivasyon düzeylerinin arttığını göstermektedir. Çelik (2019, s. 77) yaptı̆̆ çalışmada okul yöneticilerin iletişim beceri seviyeleri ile öğretmenlerin motivasyonları arasında olumlu ve orta düzeyde ilişki bulduğu sonuçlara ulaşmışır. Ulaşılan bu sonuçlar bu araştırmada bulunan sonuçları desteklemektedir.

Örgütlerde etkinlik ve verimlilik işgörenlerin başarılarına, işgörenlerin başarıları da yüksek bir motivasyon düzeyine sahip olmalarına bağlıdır (Tetik, 2019, s. 1780). Sonuç olarak bu çalışma alan yazında, spor örgütlerinde görev alan yöneticilerin iletişim beceri düzeyleri ile işgörenlerin iş motivasyon düzeylerine ilişkin bilgi ve kavrayışın artmasına katkı sağlamaktadır. Analiz sonuçlarının da gösterdiği gibi, spor örgütlerinde iletişim beceri düzeyi yüksek olan yöneticilerin bulunması işgörenlerin iş motivasyonlarının olumlu yönde artmasına sebep olmaktadır. Bu sebeple işgörenin işe olan motivasyonunu yükseltmek için yöneticilik yapan kişilerin iletişim unsurunu son derece iyi kullanmaları ve bunun için de eğitim almaları gerekmektedir. Ayrıca kadın yöneticilerin iletişim beceri düzeyleri ile erkek işgörenlerin iş motivasyon düzeyleri karşı cinsiyetlerine göre, eğitim durumu yüksek olan işgörenlerin ise olmayanlara göre iş motivasyon düzeyleri daha yüksektir. Bu sonuçlardan yola çıkarak, İstanbul Gençlik ve Spor İl Müdürlüğü’nde kadın yöneticilerin daha fazla yer almaları, işgören seçiminde eğitim durumu en az lisans mezunu olanların tercih edilmeleri, işgörenlerin iş motivasyonlarını arttıracak hizmet içi eğitim, spor ve eğlence aktivitelerinin planlanması bu kurumda verimi ve bununla beraber başarıyı artıracaktır. Son olarak iş görenlerin içsel motivasyonlarının dışsal motivasyonlarına göre yüksek olması, yöneticilerin dışsal motivasyon unsurlarını önemsemedikleri, iyi veya hiç kullanmadıkları sonucunu çıkarmaktadır. Yöneticilerin, işgörenlerin iş motivasyon düzeylerini yükseltebilmeleri için muhakkak dişsal motivasyon unsurlarını da etkili kullanmaları gerekmektedir.

\section{Etik Beyan}

"Spor Yöneticilerinin İletişim Beceri Düzeylerinin İsgörenlerin Motivasyonu Üžerine Etkisi” başliklı çalışmanın yazım sürecinde bilimsel, etik ve alıntı kurallarına uyulmuş; toplanan veriler üzerinde herhangi bir tahrifat yapılmamış ve bu çalışma herhangi başka bir akademik yayın ortamına değerlendirme için gönderilmemiştir. Bu araştırmanın verileri 01.01.2020 tarihinden önce toplandığı için etik kurul kararı zorunluluğu taşımamaktadır.

\section{Kaynakça}

Abbasoğlu, Ş. (2015). İs görenlerde örgütsel adalet algısı ve örgütsel adaletin çalışanlarn iş motivasyonu üzerindeki etkisi: bir devlet hastanesi örneği (Yüksek Lisans Tezi). Atılım Üniversitesi Sosyal Bilimler Enstitüsü, Ankara.

Akyol, P. (2019). Farklı fakültelerdeki öğrencilerin iletişim becerilerinin karşılaştırılması. Spor Eğitim Dergisi, $3(3), 71$ 77.

Altunkaya, G. (2019). Motivasyon ve örgütsel aidiyet iliskisi: Batman Üniversitesinde bir arasstrma (Yüksek Lisans Tezi). Batman Üniversitesi Sosyal Bilimler Enstitüsü, Batman.

Arslan, A. (2019). Sağlık hizmetleri meslek yüksekokulu öğrencilerinin iletişim becerileri ve öz-yeterlik algılarının çeşitli değişkenler açısından incelenmesi. On Dokuz Mayı Üniversitesi Eğitim Fakültesi Dergisi, 38(1), 146-173.

Atalay, A. (2018). Doğu Anadolu Bölgesinde çalışan Gençlik Hizmetleri ve Spor İl Müdürlüğü personelinin iletişim becerileri. Insan ve Toplum Bilimleri Arasturmalar Dergisi, 7(1), 494-513.

Atak, M. (2005). Örgütlerde resmi olmayan iletişimin yeri ve önemi. Havacllk ve Uzay Teknolojileri Dergisi, 2(2), $59-67$.

Ateş, Ö. T. ve Buluç, B. (2018). İlköğretim öğretmenlerinde motivasyon ve örgütsel bağlllı̆̆ın demografik değişkenler açısından incelenmesi. Mehmet Akif Ersoy Üniversitesi Ë̆itim Fakültesi Dergisi, 48, 01-30.

Balıbey, M. ve Öndaş, N. K. (2018). İdari personelin demografik özellikleriyle iş tatmini ve meslek motivasyon ilişkisi: Munzur Üniversitesi örneği. Firat Üniversitesi Sosyal Bilimler Dergisi, 28(1), 171-186.

Biçer, T. (2006). Şampiyonluğun psikolojisi. İstanbul: Beyaz Yayınları.

Borca, C. ve Baesu, V. (2014). A possible managerial approach for internal organizational communication characterization. Procedia-Socialand Behavioral Sciences. 124, 496-503.

Çelik, M. (2013). İstanbul ili Arnavutköy ilçesindeki ortaögretim kurumlarnda görev yapan yöneticilerin iletişim becerilerinin ögretmen motivasyonlar ve akademike tükenmişlikleri üzerine etkisi (Yüksek Lisans Tezi). Yeditepe Üniversitesi Sosyal Bilimler Enstitüsü, İstanbul. 
Çelik, S. (2019). İlkokul ögretmenlerinin algzladlklar yönetici iletişim becerileri ile ögrretmenlerin motivasyonu ve iş doyumu arasındaki ilişki (Yüksek Lisans Tezi). Kırşehir Ahi Evran Üniversitesi Sosyal Bilimler Enstitüsü, Kırşehir.

Çetinkaya, Z. (2011). Türkçe öğretmen adaylarının iletişim becerilerine ilişkin görüşlerinin belirlenmesi. Kastamonu Ë̆itim Dergisi. 19 (2), 567-576.

Demirtaş, M. (2010). Örgütsel iletişimin verimlilik ve etkinliğinde yararlanılan iletişim araçları ve halkla ilişkiler filmleri örneği. Marmara Üniversitesi İIBF Dergisi, 28(1), 411-444.

Dündar, S., Özutku, H. ve Taşpınar, F. (2007). İçsel ve dişsal motivasyon araçlarının işgörenlerin motivasyonu üzerindeki etkisi: ampirik bir inceleme. Ticaret ve Turizm Eğitim Fakültesi Dergisi, 2(7), 105-119.

Ersarı, G. ve Naktiyok, A. (2012). İşgörenin içsel ve dişsal motivasyonunda stresle mücadele tekniklerinin rolü. Atatürk Üniversitesi Sosyal Bilimler Enstitüsü Dergisi, 16(1), 81-101.

Ertürk, R. (2016). Öğretmenlerin iş motivasyonları. Eğitim Kuram ve Uygulama Araştırmalar Dergisi, 2(3), 1-15.

Fidan, E. (2019). Liderlik stilinin çalışan motivasyonu ve örgütsel vatandaşlle davranış ǚerine etkisi (Yüksek Lisans Tezi). Nişantaşı Üniversitesi Sosyal Bilimler Enstitüsü, İstanbul.

Gedik, T., Çil, M., Korkut, D. S., Kaya, M. Y. ve Şimşek, B. (2018). Düzce orman ürünleri sanayi yöneticilerinin iş motivasyonu üzerine bir araştırma. Türkiye Ormancıllk Dergisi, 19(1), 91-97.

Gülüm, R. (2019). Beden eğitimi ve spor ögretmenlerinin iletişim becerileri ile meslek tutum düzeyleri arasindaki ilişkinin incelenmesi (Yüksek Lisans Tezi). Atatürk Üniversitesi Kış Sporları ve Spor Bilimleri Enstitüsü, Erzurum.

Karaçar, E. (2019). Otel çalışanlarının iş tatmini ve motivasyon düzey değişkenleri üzerine bir araştırma Sinop örneği. Sinop Üniversitesi Sosyal Bilimler Dergisi, 3(1), 55-78.

Karasar, N. (2006). Bilimsel araştırma yöntemleri. Ankara: Nobel Yayın Dağıtım.

Kıraç, E. (2012). Örgütsel iletişsimin örgütsel bağllık algılaması üzerindeki etkileri ve bir araştırma (Yüksek Lisans Tezi). Pamukkale Üniversitesi Sosyal Bilimler Enstitüsü, Denizli.

Koçel, T. (2001). İsletme yöneticiliği: Yönetim ve organizasyon. İstanbul: Beta Yayınları.

Korkut, F. (1996). İletişim becerilerini değerlendirme ölçeğinin geliştirilmesi: güvenirlik ve geçerlik çalışması. Türk Psikolojik ve Damisma ve Rehberlik Dergisi, 2(7), 18-23.

Kumcağız, H., Yılmaz, M., Çelik, S. B. ve Avcı, İ. A. (2011). Hemşirelerin iletişim becerileri: Samsun ili örneği. Dicle Tip Dergisi, 3(1), 49-56.

Mottaz, J. C. (1985). The relative importance of intrinsic and extrinsic rewards as determinants of wok satisfaction. The Sociological Quarterly, 3(26), 365-385.

Nacar, F. S. ve Tümkaya, S. (2011). Sınıf öğretmenlerinin iletişim ve kişilerarası problem çözme becerilerinin incelenmesi. Elementary Education Online, 10(2), 493-511.

Nal, M. ve Sevim, E. (2019). Paternalist liderliğin iş motivasyonu üzerine etkisi: sağllk çalışanları üzerinde bir araştırma. Gümüshane Üniversitesi Sağhk Bilimleri Dergisi, 8(4), 397-410.

Oskay, Ü. (2019). İletişimin ABC'si. İstanbul: İnk1lâp Yayınevi.

Orhaner, E. ve Mutlu, S. (2018). Sağlık personelinin iş tatmininin motivasyon üzerine etkisi. Uluslararası Sağhlk Yönetimi ve Stratejileri Araștırma Dergisi, 4(1), 74-93. Erişim adresi:

Öksüz, N. (2018). Spor yöneticilerinin iletişim becerileri ile öz etkililik-yeterlilik düreylerinin değerlendirilmesi (Yüksek Lisans Tezi). İstanbul Gelişim Üniversitesi Sağlık Bilimleri Enstitüsü, İstanbul.

Özday1, N. (2011). Futbol hakemlerinin duygusal zekâ ve iletişim beceri düzeyleri arasındaki ilişkinin incelenmesi (Yüksek Lisans Tezi). Gaziantep Üniversitesi Sağlık Bilimleri Enstitüsü, Gaziantep.

Öztürk, T. Ö., ve Soytürk, M. (2019). Sporcu alg1larına göre antrenör iletişim becerileri. Manas Sosyal Araştırmalar Dergisi, 8(1), 576-583.

Sert, A. (2018). Kamu ve özel okul öncesi eğitim kurumu yöneticilerinin iletişim becerilerinin incelenmesi (Yüksek Lisans Tezi). Marmara ve İstanbul Sabahattin Zaim Üniversiteleri Eğitim Yönetimi ve Denetimi Ortak Yüksek Lisans Program1, İstanbul.

Serttaş, A. ve Tanyıldızı, N. İ. (2019). Kamu iç denetçilerinin iletişim becerilerinin incelenmesi. Gað̧iantep Üniversitesi Sosyal Bilimler Dergisi, 18(3), 966-989.

Şimşek, M. Ş. (2002). Yönetim ve organizasyon. Konya: Günay Ofset.

Tabachnick, B. G. ve Fidell. L.S. (2013). Using multivariate statistics. Boston: Pearson.

Tetik, S. (2019). Kamu örgütlerinde örgütsel sosyalleşmenin iş motivasyonu üzerindeki etkisi: İhsaniye ilçesinde bir araştırma. Issletme Araştırmalar Dergisi. 11 (3): 1779-1791.

Timuroğlu, M. K. ve Balkaya, E. (2017). Örgütsel iletişim ve motivasyon ilişkisi -bir uygulama-. International Journal of Sociallnquiry, 9(2), 89-113.

Tutar, H. (2003). Örgütsel iletişim. Ankara: Seçkin Yayıncılık.

Yanık, M. (2015). Spor türü ve diğer bazı değişkenlerin beden eğitimi ve spor yüksekokulu öğrencilerinin iletişim beceri düzeylerine etkisi. International Journal of Human Sciences, 12(2), 1366-1376.

Yıldız, S. (2017). Kamu kurumlarnda iletişim becerileri ve çalışan motivasyonuna iliş̧kin bir araştırma: ISKİ örneği (Yüksek Lisans Tezi). Nişantaşı Üniversitesi Sosyal Bilimler Enstitüsü, İstanbul.

Yllmaz, F. (2009). Eğitim örgütlerinde örgüt kültürünün ögretmenlerin iş motivasyonu üzerindeki etkisi (Yüksek Lisans Tezi). Selçuk Üniversitesi Sosyal Bilimler Enstitüsü, Konya. 
Yirmibeşcik, M. (2015). Sunf ögretmenlerinin yöneticilerin iletişim becerilerinden dolayı kazandıklar motivasyonun iş doyumuna etkisi (Yüksek Lisans Tezi). İstanbul Aydın Üniversitesi Sosyal Bilimler Enstitüsü, İstanbul. Zillığlu, M. (2007). İletişim nedir? İstanbul: Cem Yayınevi.

\section{EXTENDED ABSTRACT}

Communication is an important concept that is an essential requirement in every moment of life. In fact, while establishing successful relationships in social life and organizations depends on effective communication. Face-to-face relationship in the current in the profession, the quality of the communication skills of individuals are said to be very important. Communication is also very important for organizations. Organizational communication is expressed as employees exchanging messages, interacting and cooperating to achieve the goals and objectives of the organization. Also among that employee information, organizational communication, data, located in the function of transmitting thoughts and perceptions.

In organizations that do not have a good communication structure, it is not possible to plan, execute activities and ensure coordination. Employees have the opportunity to learn how to do their jobs and what their superiors or other employees think about themselves through communication. Organizational communication plays an important role in the management and it is also effective for employees to have positive attitudes. Effectiveness of organizational communication also creates a positive effect on employees' behaviours with factors such as job satisfaction, motivation and organizational commitment. In addition, it is extremely important for the manager to have effective communication skills. Because communication is the most basic tool used by managers in an organizational environment.

Motivation is a set of cyclical processes that constantly mobilize and direct the individual's behaviour for specific purposes. The performance of employees and organizations can be increased with motivation. Job motivation is examined internally and externally in two dimensions.

In this study, the effects of the communication skill levels of the sports managers working at the Istanbul Youth and Sports Provincial Directorate on the work motivation of the employees were investigated. The universe of the research was composed of 2082 employees (88 managers, 1994 employees) who worked in the Istanbul Youth and Sports Provincial Directorate, and 489 employees (77 managers, 412 employees) participated in the study on a voluntary basis. The sample group was accepted to represent the universe $(23.4 \%)$.

In the first part of the questionnaire used to collect data in the research, demographic information was requested. Communication Skills Assessment Scale (CSAS), which was developed and developed by Korkut (1996), was used for managers. For the employees, the Business Motivation Scale (BMS-24-item) developed by Mottaz (1985) and adapted in Turkish by Dündar et al. (2007) was used. As a result of the research, it was determined that the communication skill levels of the managers are at a high level (Avg.=4.32) and the motivation levels of the employees are at a medium level (Avg.=3.27). In addition, a very weak correlation was found between the communication skill levels of the managers participating in the research and the job motivation levels of the employees $(r=.079 ; \mathrm{p}>.05)$.

The reason for the high level of communication skills of the managers participating in the research can be shown as the fact that they all have undergraduate and higher education. Individuals, who have undergraduate education or higher are expected to improve themselves, become aware of their inadequate skills and make efforts to increase these skills. They found that communication skills levels were high in a study conducted by Serttass and Tanyıldız1 (2019) on public inspectors.

According to the results of the research, it is seen that the job motivation levels of the employees are at a medium level. In order for the employees to have high levels of work motivation, both internal and external motivation levels should be high. To ensure this is primarily the task of managers. The internal motivation of the employees participating in the research is much higher than the external motivation levels. This situation shows that the employees have problems with external tools such as management, salary, promotion, reward, communication, training needs and physical conditions. In studies conducted by Ersariet al. (2012) and Ertürk (2016), it was found that the job motivation levels of the employees are at a medium level. 
According to the responses of the employees, there were significant differences in the gender variable. It has been revealed that the job motivation levels of male employees are higher than female employees. In a study conducted by Çelik (2013), it was concluded that there was a significant difference between the gender variable and motivation level in favour of men.

According to another research result, a very weak correlation emerged between the communication skill levels of the managers and the job motivation levels of the employees. This result shows that the increase in the communication skill levels of the managers has a little effect on the increase in the job motivation levels of the employees. In a study conducted by Çelik (2019), it was concluded that there is a positive and moderate relationship between the communication skills levels of school administrators and teachers' motivations.

As the research results show, managers with a high level of communication skills in sports organizations have a positive influence on the job motivation of employees. In order to increase the motivation of the employee, the people who are managing must use their communication skills extremely well and get training on this subject. In addition, the communication skill levels of female managers, the job motivation levels of male employees and the job motivation levels of employees with higher education are also higher.

As a result, it can be said that the choice of employees with high educational status, a limited number of female managers in sports organizations, and the planning of in-service training, sports and entertainment activities that will increase the job motivation of employees will increase efficiency and success in sports organizations. Also, according to the results of the research, the high motivation of the employees reveals that the managers do not care about external motivation and do not use it well or at all. Managers must use external motivation factors effectively in order to increase their work motivation levels. 